\title{
Production of amylase by Arthrobacter psychrolactophilus
}

Received: 19 July 2004 / Accepted: 19 April 2005 / Published online: 2 June 2005

(C) Society for Industrial Microbiology 2005

\begin{abstract}
Arthrobacter psychrolactophilus ATCC 700733 grew with a doubling time of $1.5-2.3 \mathrm{~h}\left(22^{\circ} \mathrm{C}\right)$ and produced up to 0.2 units $/ \mathrm{mL}$ (soluble starch assay) of extracellular amylase in tryptic soy broth without dextrose (TSBWD) containing $0.5 \%$ or $1.0 \%(\mathrm{w} / \mathrm{v})$ soluble starch or maltose as the fermentable substrate. Timecourse experiments in media containing soluble starch as substrate showed that amylolytic activity appeared in cultures at $24 \mathrm{~h}$ (after exponential growth had ceased), reached peak levels in 72-96 h, and declined rapidly after reaching peak levels. Peak levels were highest in TSBWD containing $1.0 \%$ soluble starch. Proteolytic activity appeared at about the same time as amylolytic activity and increased during the period of amylase production. Significant amylase production was not observed in cultures in TSBWD with $0.5 \%$ glucose or in cultures grown at $28^{\circ} \mathrm{C}$, but low levels of amylase were observed in TSBWD cultures grown at $19-23^{\circ} \mathrm{C}$ which contained no added carbohydrate. A single band of activity was observed after electrophoresis of supernatant fractions in non-denaturing gels, followed by in situ staining for amylolytic activity. The amylase possessed a raw starch-binding domain and bound to uncooked corn, wheat or potato starch granules. It was active in the Phadebas assay for $\alpha$-amylase. Activity was maximum on soluble starch at a temperature between $40^{\circ} \mathrm{C}$ and $50^{\circ} \mathrm{C}$. The amylase after purification by affinity chromatography on raw starch granules exhibited two starch-binding protein bands on SDS gels of $105 \mathrm{kDa}$ and $26 \mathrm{kDa}$.
\end{abstract}

Keywords Amylase $\cdot$ Starch $\cdot$ Psychrophile Psychrotroph · Arthrobacter psychrolactophilus

M. R. Smith $(\bowtie) \cdot$ J. C. Zahnley

U.S. Department of Agriculture,

Western Regional Research Center, 800 Buchanan Street,

Albany, CA 94710, USA

E-mail: mrsmith@pw.usda.gov

Tel.: + 1-510-5595865

Fax: + 1-510-5595777

\section{Introduction}

Cold-tolerant bacteria often produce enzymes having optimum activity at moderate to low temperatures. These enzymes are increasingly of commercial and scientific interest because they might be used in applications at low temperature and because there is scientific interest in the relationship between protein structure and the thermal stability of enzymes. Enzymes with maximal activity at low to moderate temperatures often have greater specific activities at low temperatures than enzymes with higher temperature maxima [4], which could result in reduced costs for enzymes used for low-temperature applications if other factors are equal. We are interested in amylases with moderate to low temperature maxima to improve a low- to moderate-temperature mechanical process for separating wheat gluten from starch granules, where the starch granules are considered a low-value waste product.

Arthrobacter psychrolactophilus ATCC 700733 is a cold-tolerant Gram positive soil bacterium isolated from farm soil in Pennsylvania [9]. It is an unusual species of Arthrobacter in that it grows at $0^{\circ} \mathrm{C}$, ferments lactose, and produces a psychrophilic, cell-associated $\beta$-galactosidase [9]. A . psychrolactophilus also produces glucosidases, amylase, and gelatinase [10]. The properties of the $\beta$-galactosidase were described in detail [16] because it could be used at low temperatures to produce milk with reduced lactose concentrations, but other enzymes which the bacterium produces and which might be of interest, such as amylase, were described in less detail. In this article, we describe the production and partial characterization of amylase by $A$. psychrolactophilus.

\section{Materials and methods}

Bacterial strains, culture media, and growth conditions

A. psychrolactophilus ATCC 700733 was purchased from the American Type Culture Collection (Manassass, Va.) 
and maintained by bi-weekly transfer on slants of Bacto tryptic soy agar (Difco Laboratories, Detroit, Mich.). Amylase production was carried out using Bacto tryptic soy broth without dextrose (TSBWD; Difco Laboratories) supplemented with $50 \mathrm{mM}$ HEPES, $\mathrm{pH} 7.0$, and $0.5-1.0 \%(\mathrm{w} / \mathrm{v})$ carbohydrate in $250-\mathrm{mL}$ Erlenmeyer flasks containing $100 \mathrm{~mL}$ of medium or in 3-L Fernbach flasks containing $1 \mathrm{~L}$ of medium. Glucose was added as a sterile solution after autoclaving but all other carbohydrates were added prior to autoclaving. Cultures were inoculated ( $1 \%$ vol.) with 1-day to 2-day cultures in TSB and incubated at $22^{\circ} \mathrm{C}$ with shaking on a rotary shaker. Cell densities were monitored at $660 \mathrm{~nm}$ in a Cary 100 spectrophotometer (Varian, Walnut Creek, Calif.).

\section{Chemicals}

3,5-Dinitrosalicylic acid (DNS) and raw corn, wheat and potato starch were purchased from Sigma Chemical Co. (St. Louis, Mo.). Azocasein was purchased from Nutritional Biochemicals Corp. (Cleveland, Ohio). The Sigma Diagnostics infinity amylase assay reagent was purchased from Sigma Chemical Co. or from Thermo DMA (Louiseville, Colo.). Phadebas starch assay tablets were purchased from Pharmacia Upjohn Co. (Uppsala, Sweden).

\section{Assays}

Assays for amylase were performed in duplicate or triplicate using DNS reagent and soluble starch as substrate, the Sigma Diagnostics infinity amylase reagent, or the Phadebas assay for $\alpha$-amylase.

Soluble starch assays for amylase (DNS assay) were carried out in a total reaction volume of $1.5 \mathrm{~mL}$ by adding $100-300 \mu \mathrm{L}$ of sample to assay buffer $(50 \mathrm{mM}$ Bis-Tris, pH $6.5,3 \mathrm{mM} \mathrm{CaCl} 2,1.0 \%$ soluble starch, $0.02 \% \mathrm{NaN}_{3}$ ). Aliquots of $300 \mu \mathrm{L}$ were then assayed for reducing sugar using DNS color reagent [14]. Absorbances were read in a spectrophotometer at $540 \mathrm{~nm}$ and activity was calculated from a standard curve using glucose as the standard. Reagent blanks containing boiled (10 $\mathrm{min})$ samples or samples taken at time zero were subtracted from the readings.

Sigma infinity amylase assay reagent contained 4-nitrophenyl $\alpha$-maltoheptaoside-4, $6 o$-ethylidene as the substrate. Assays were carried out at $22^{\circ} \mathrm{C}$ for $10 \mathrm{~min}$ using sample volumes of $20-100 \mu \mathrm{L}$ and $1.0 \mathrm{~mL}$ of Sigma infinity assay reagent. The progress of the reaction was monitored continuously using a Cary 100 computerized spectrophotometer with thermal controller and enzyme kinetics software (Varian). Rates of change of absorbance were calculated from the linear portions of the curve and units of activity $/ \mathrm{mL}$ were calculated according to the instructions provided, using an extinction coefficient of 10.13 absorbance units $/ \mathrm{mM}$ (light path $1.0 \mathrm{~cm}$ ).

The Phadebas assay for amylase was performed at $40^{\circ} \mathrm{C}$ according to the manufacturer's directions [1].
Protease was assayed at the indicated temperature and time in a total volume of $300 \mu \mathrm{L}$, using azocasein solution (50 mM MES, pH 6.5, $3 \mathrm{mM} \mathrm{CaCl} 2,0.02 \%$ $\mathrm{NaN}_{3}, 1 \%$ azocasein) as the substrate and $60-\mu \mathrm{L}$ samples $[6,13]$. Absorbances were read at $440 \mathrm{~nm}$ and reagent blanks containing water instead of sample were subtracted from the readings. One unit of activity was the amount of azocaseinase required to produce a change of 1.0 absorbance unit in $24 \mathrm{~h}$ under the conditions of the assay [13].

Protein was assayed using the Bradford dye-binding assay and Biorad protein reagent (Biorad Laboratories, Hercules, Calif. [2]).

\section{Crude amylase preparations}

Crude amylase was prepared from supernatant fractions from $100-\mathrm{mL}$ or $1-\mathrm{L}$ cultures (centrifuged at 13,000 $16,000 \mathrm{~g}$ for $20 \mathrm{~min}$ at $4^{\circ} \mathrm{C}$ ). Protein concentrations in unconcentrated fractions ranged from $5 \mu \mathrm{g} / \mathrm{mL}$ to $10 \mu \mathrm{g} /$ $\mathrm{mL}$ as estimated from fractions which had been concentrated by ultrafiltration. Supernatant fractions were concentrated 50- to 100 -fold by ultrafiltration using a Pellicon XL tangiential flow ultrafiltration device (Millipore Corp., Bedford, Mass.) and Ultracell 10 PLCGC membrane (10,000 Da cut-off). Final protein concentrations ranged from $600 \mu \mathrm{g} / \mathrm{mL}$ to $1,200 \mu \mathrm{g} / \mathrm{mL}$.

\section{Native PAGE}

Concentrated supernatant fractions were subjected to PAGE under non-denaturing conditions using $1.5-\mathrm{mm}$ $4 \%$ stacking gels, $6.5 \%$ separating gels, and a Biorad minigel system. Samples were prepared by adding concentrated supernatant fraction $(120 \mu \mathrm{L})$ containing $236 \mu \mathrm{g} / \mathrm{mL}$ protein to $80 \mu \mathrm{L}$ of sample buffer $(20 \mu \mathrm{L}$ $0.5 \mathrm{M}$ Tris- $\mathrm{HCl}, \mathrm{pH} 6.8,40 \mu \mathrm{l}$ of $60 \%$ glycerol, $20 \mu \mathrm{L}$ of $0.05 \%$ bromphenol blue). Samples were then applied to $1.0-\mathrm{mm}$ minigels and electrophoresis was carried out at $200 \mathrm{~V}$ for approximately $55 \mathrm{~min}$, using a running buffer consisting of $25 \mathrm{mM}$ Tris and $192 \mathrm{mM}$ glycine, $\mathrm{pH} 8.3$. Gels were stained for amylase activity by incubating them for $7 \mathrm{~min}$ in a buffer solution $(50 \mathrm{mM}$ Bis-Tris, $\mathrm{pH} 6.5,3 \mathrm{mM} \mathrm{CaCl}_{2}, 1 \%$ soluble starch), rinsing briefly with water, and then flooding with Lugol's iodine solution ( $5 \mathrm{~g}$ of $\mathrm{I}_{2}, 10 \mathrm{~g}$ of $\mathrm{KI}$ in $100 \mathrm{~mL}$ water) to reveal bands of clearing.

\section{SDS-PAGE}

SDS-PAGE was carried out using 10-well Novex BisTris, $1.0-\mathrm{mm}$ NuPAGE SDS $10 \%$ polyacrylamide precast gels (Invitrogen Corp., Carlsbad, Calif.) at $160 \mathrm{~V}$ for $60 \mathrm{~min}$, using the MES-SDS running buffer supplied by Invitrogen. The gels were then fixed and stained with Coomassie blue according to standard protocols, imaged on an IS-1000 digital imaging system (Alpha Innotech Co. San Leandro, Calif.), and molecular weights 
were estimated using molecular weight markers and the software provided.

\section{Results}

Time-course for growth and amylase production

Cultures grew from a $1 \%$ (vol.) inoculum in TSBWD medium at $22^{\circ} \mathrm{C}$ with generation times of $1.5-2.0 \mathrm{~h}$. Fig. 1a-d shows the effects of growth substrate on growth rate, final cell density, amylase production, and protease production. The accumulation of reducing sugars from the breakdown of starch was also monitored.

Cultures inoculated into TSBWD plus $1 \%(\mathrm{w} / \mathrm{v})$ soluble starch (Fig. 1a) grew with a doubling time of

Fig. 1 Time-course for growth, amylase, and protease production by $A$. psychrolactophilus in TSBWD medium. a $1 \%(\mathrm{w} / \mathrm{v})$ soluble starch, b $0.5 \%(\mathrm{w} / \mathrm{v})$ soluble starch, c $0.5 \%$ glucose, $\mathbf{d}$ no added carbohydrate. A $1 \%(\mathrm{v} / \mathrm{v})$ inoculum consisting of a 2-day culture of A. psychrolactophilus in TSB was inoculated into $100 \mathrm{~mL}$ of TSBWD containing the indicated supplement and incubated with shaking on a rotary shaker at $22^{\circ} \mathrm{C}$. Samples $(5 \mathrm{~mL})$ were taken at intervals and assayed for absorbance, amylolytic activity, proteolytic activity, and reducing sugar (data not shown). - Absorbance $(660 \mathrm{~nm})$, o amylolytic activity, $\square$ Proteolytic activity
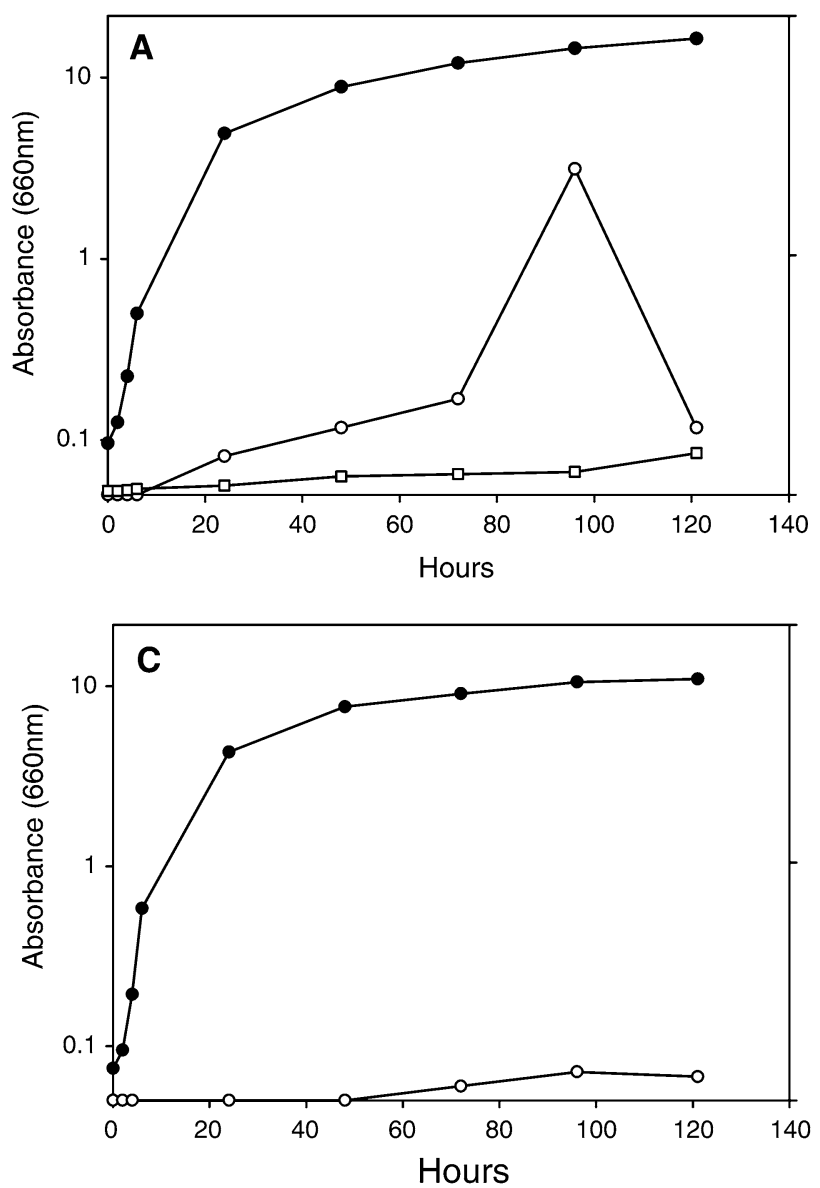

$2.0 \mathrm{~h}$ and exponential growth ceased within the first $24 \mathrm{~h}$. Final cell densities of 16 absorbance units $(660 \mathrm{~nm})$ were achieved. Amylase started to appear after $24 \mathrm{~h}$ of incubation and reached a peak level of about 7 units $/ \mathrm{mL}$ (Sigma assay) at $96 \mathrm{~h}$. Most of the amylase was produced during the period when cell densities were high and growth was not exponential. Amylase was not detected in cultures in exponential growth. Amylolytic activity rapidly declined after $96 \mathrm{~h}$, suggesting that the amylase was not stable in the cultures over extended periods at $22^{\circ} \mathrm{C}$. The sharp increase and subsequent decline in amylolytic activity observed between $24 \mathrm{~h}$ and $121 \mathrm{~h}$ was verified by repeating assays on samples which had been saved by freezing. Reducing sugar (data not shown) generated from the hydrolysis of the starch was less than $400 \mathrm{nmol} / \mathrm{mL}$ throughout the incubation period. Reducing sugar did not accumulate probably because cell densities were high (approximately 5.0 absorbance units) by the time measurable levels of amylolytic activity began to appear.

Extracellular protease activity in starch cultures was monitored because A. psychrolactophilus was reported to produce gelatinase [9], which could be a potential source of problems for interpreting the results of assays for amylase activity. Measurable extracellular azocaseinase activity began to appear in cultures on $1 \%$ starch at about the same time $(24 \mathrm{~h})$ that amylase appeared and gradually increased to a maximum of 0.9 units $/ \mathrm{mL}$ at
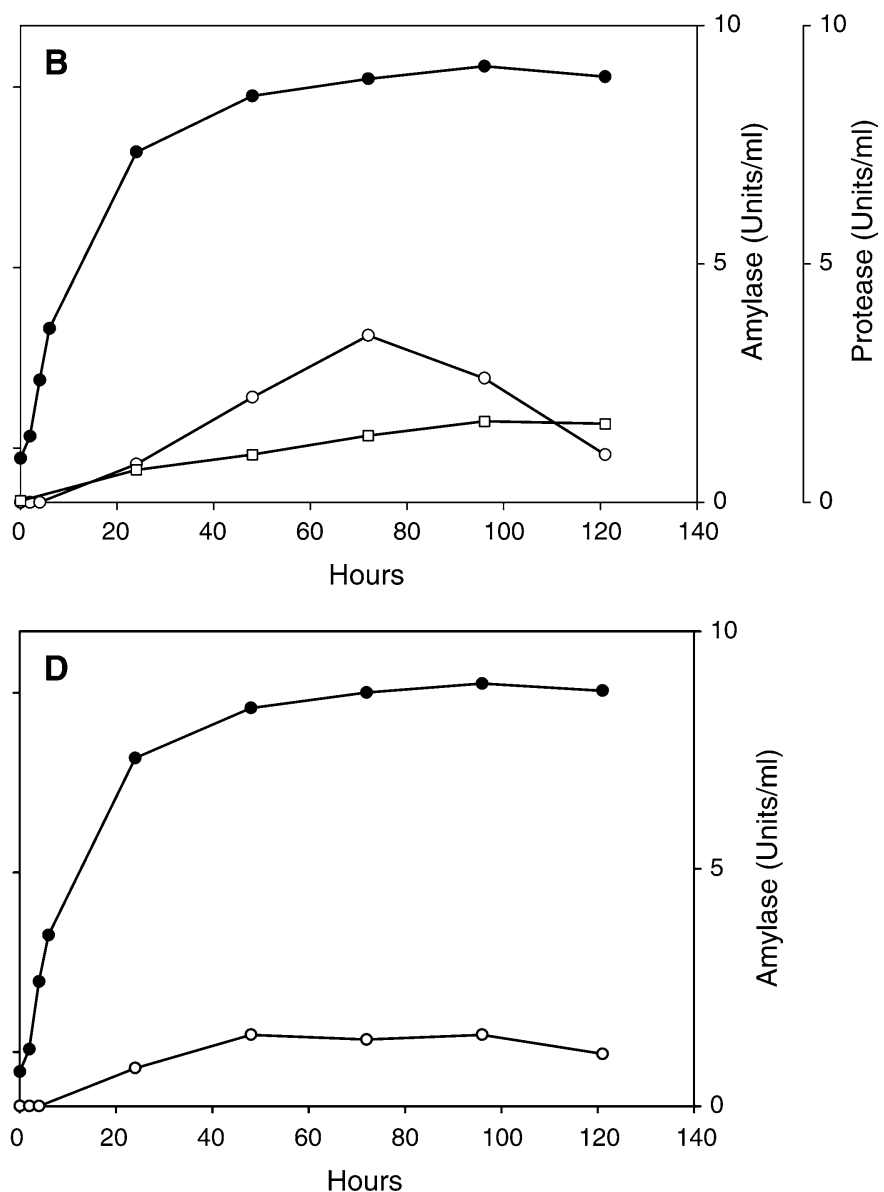
$121 \mathrm{~h}$. This level is probably insufficient to cause problems over short $(<3 \mathrm{~h})$ incubation periods.

The time-course of growth, amylase, and protease production in TSBWD containing $0.5 \%(\mathrm{w} / \mathrm{v})$ soluble starch (Fig. 1b) resembled that in TSBWD plus $1.0 \%$ starch, except that peak amylolytic activity (approximately 3.5 Sigma units $/ \mathrm{mL}$ ) and final cell densities (13 absorbance units at $660 \mathrm{~nm}$ ) were slightly lower than on $1 \%$ starch and peak levels of amylase were reached in $72 \mathrm{~h}$ instead of $96 \mathrm{~h}$. The doubling time during exponential growth was the same as in $1 \%$ starch and amylolytic activity declined rapidly after reaching a peak. As with cultures in $1 \%$ soluble starch, reducing sugar from the hydrolysis of starch did not accumulate at any time during the incubation period.

Glucose seemed to repress the production of amylase. When cultures were grown in TSBWD containing $0.5 \%$ glucose (Fig. 1c) as the substrate, amylolytic activity appeared late $(72 \mathrm{~h})$ if at all and remained at less than 0.7 units $/ \mathrm{mL}$ (Sigma assay) throughout the incubation period. Cultures grew somewhat faster on glucose (approximately $1.5 \mathrm{~h}$ ) than on starch and final cell densities (10-11 absorbance units) were slightly lower than cell densities obtained with starch medium.

Amylase (1.5 units/mL, Sigma assay) was produced in TSBWD even if no carbohydrate substrate was added to the medium (Fig. 1d). The absence of a carbohydrate substrate did not significantly slow the doubling times of the cultures $(1.9 \mathrm{~h})$ relative to starch medium $(2.0 \mathrm{~h})$, but the final cell densities (11 absorbance units) were somewhat lower than on starch medium and about the same as on glucose medium.

\section{Native PAGE}

A. psychrolactophilus was reported to produce several kinds of extracellular enzymes and it was possible that it produced more than one type of amylase. A concentrate of a supernatant fraction was subjected to electrophoresis under non-denaturing conditions and the native gel was stained for amylase activity (Fig. 2). Only a single band of amylolytic activity was observed, suggesting that $A$. psychrolactophilus produced a single type of amylase. The amylase appeared to be an $\alpha-$ amylase because it hydrolyzed starch in the Phadebas assay (data not shown), which uses a dye-labeled starch substrate which is not hydrolyzed by $\beta$-amylases [1] and it was active in the Sigma infinity amylase assay, which used an ethylidene-blocked maltoheptaoside substrate which is not hydrolyzed by glucoamylases or $\beta$-amylases.

\section{Storage properties}

Amylase preparations from supernatant fractions of cultures that had been concentrated 80 - to 100 -fold by ultrafiltration (10,000 Da cut-off) slowly lost activity

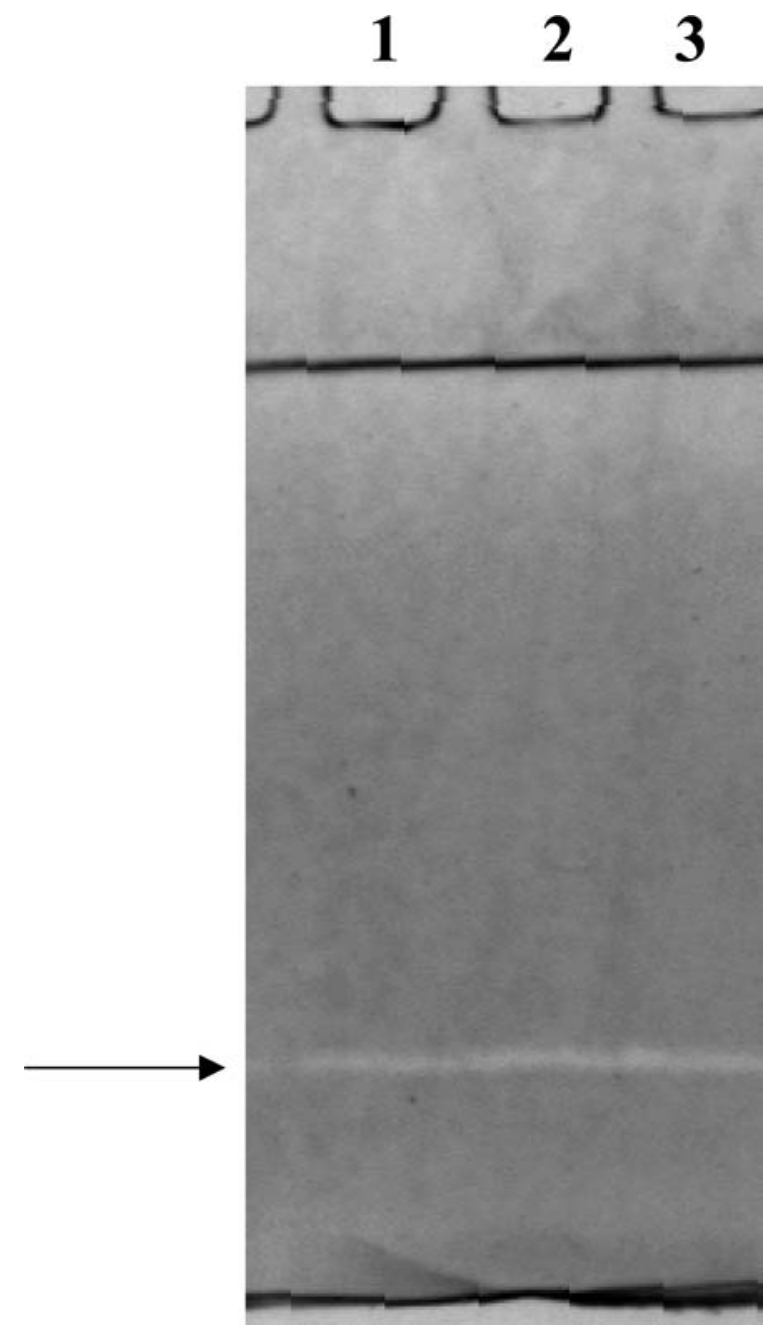

Fig. 2 Native PAGE stained for amylolytic activity. A concentrated supernatant fraction from a culture of $A$. psychrolactophilus grown in TSBWD medium plus $1.0 \%$ maltose was loaded onto a $6.5 \%$ polyacrylamide gel and subjected to electrophoresis under non-denaturing conditions. The gel was then washed, incubated with $1 \%$ soluble starch in $50 \mathrm{mM}$ Bis-Tris, $\mathrm{pH} 6.5,3 \mathrm{mM} \mathrm{CaCl}_{2}$, rinsed, and then flooded with Lugol's iodine solution to stain for amylolytic activity. A single band of activity (arrow) was evident: lane $12.4 \mu \mathrm{g}$ of protein, lane $24.7 \mu \mathrm{g}$ of protein, lane $39.4 \mu \mathrm{g}$ of protein

when stored in a refrigerator at $5^{\circ} \mathrm{C}$ (Fig. 3). Concentrated enzyme preparations retained approximately half their activity after storage for 72 days. Amylase activity also appeared to tolerate freezing, because no loss of activity was seen when a supernatant fraction was stored overnight at $20^{\circ} \mathrm{C}$, then thawed, and assayed the next day.

\section{Temperature optimum}

A. psychrolactophilus amylase exhibited maximum activity on soluble starch at $40-50^{\circ} \mathrm{C}$ in 3 -h incubations using unconcentrated supernatant fractions of cultures (Fig. 4). Significant activity was observed at temperatures of $20^{\circ} \mathrm{C}$ or lower, suggesting that the enzyme could be used for ambient or low-temperature applications. 


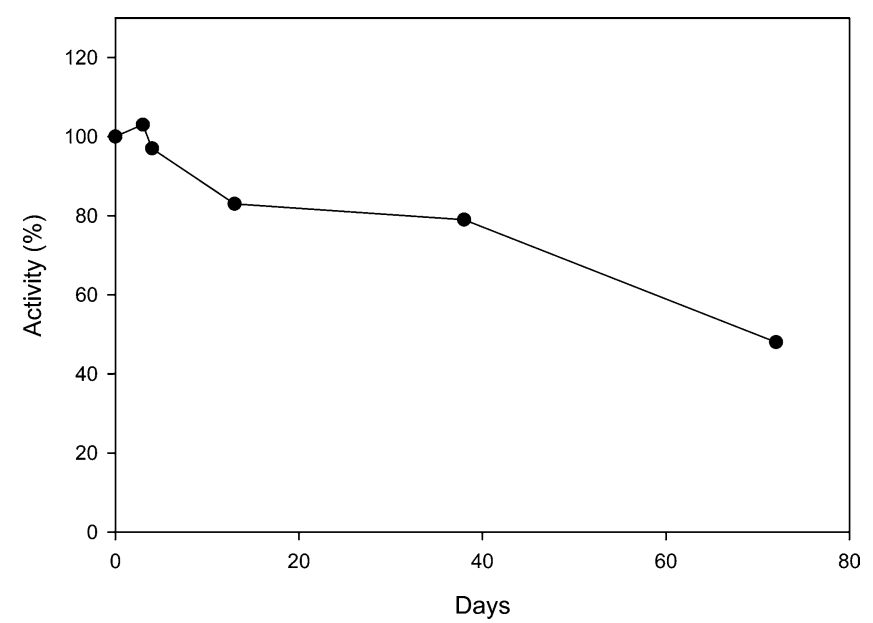

Fig. 3 Stability during storage of amylolytic activity in concentrates of supernatant fractions. Concentrated supernatant fractions were stored in the refrigerator at $5^{\circ} \mathrm{C}$ and assayed on soluble starch at various times during storage

\section{Binding to raw starch}

The ability of $A$. psychrolactophilus amylase to bind to raw corn, wheat, and potato starch at $0^{\circ} \mathrm{C}$ was determined by incubating unconcentrated supernatant fractions with starch suspensions for $15 \mathrm{~min}$, removing the starch granules by centrifugation, and then assaying for supernatant activity using soluble starch as the substrate. The activity remaining after adsorption with starch was compared with the activity in the untreated supernatant fraction. Table 1 shows that the amylase apparently possessed a raw starch-binding domain and bound to uncooked corn, wheat, or potato starch granules. Binding appeared to be slightly greater for corn starch than for wheat or potato starch.

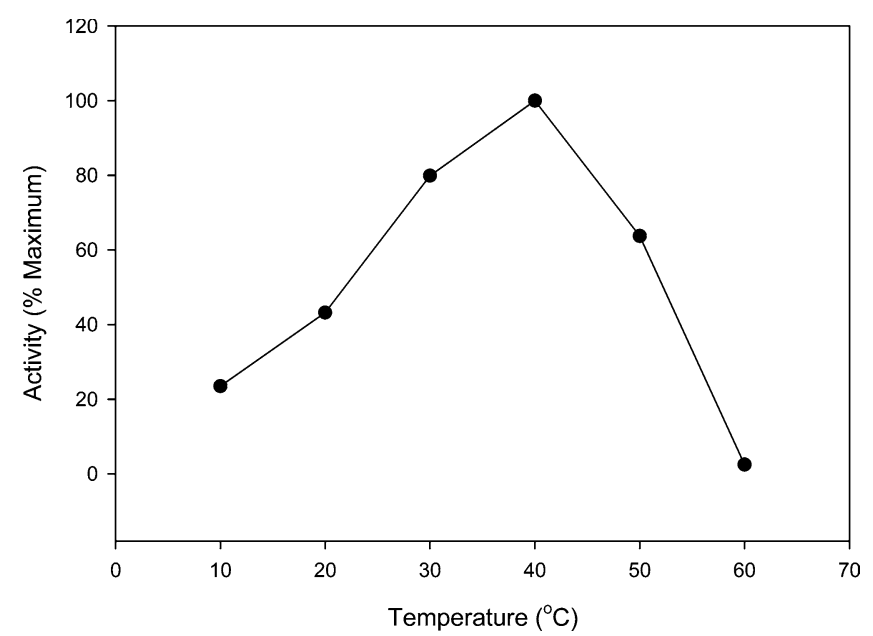

Fig. 4 Temperature profile of amylolytic activity. Unconcentrated supernatant fraction $(300 \mu \mathrm{L})$ was assayed by incubation with $1.5 \mathrm{~mL}$ of reaction mixture containing $1.0 \%(\mathrm{w} / \mathrm{v})$ soluble starch for $3 \mathrm{~h}$ at the indicated temperatures, then measuring by DNS assay the reducing sugar that was liberated. Maximum activity was 0.14 units $/ \mathrm{mL}$

\section{Purification}

The ability of the amylase to bind to raw corn starch granules was exploited to purify it 23 -fold in a single step (Table 2). Samples $(1.0 \mathrm{~mL})$ of concentrated supernatant fraction from a 72 -h culture on $1 \%(\mathrm{w} / \mathrm{v})$ maltose were incubated with $100 \mathrm{mg}$ of uncooked corn starch granules at $4^{\circ} \mathrm{C}$ for $15 \mathrm{~min}$, then filtered via syringe through a $10 \mu \mathrm{m}$ Mobicol M1002 filter (Mo Bi Tec, Marco Island, Fla.). The starch granules were then washed three times with $3.0 \mathrm{~mL}$ of $50 \mathrm{mM}$ MES, pH $6.5,3 \mathrm{mM} \mathrm{CaCl}_{2}$, and purified amylase was eluted from the granules with $1.0 \mathrm{~mL}$ of a solution containing $50 \mathrm{mM}$ Bis-Tris, $\mathrm{pH} 6.5$, $2 \mathrm{mM} \mathrm{CaCl}_{2}, 0.02 \% \mathrm{NaN}_{3}$, and $1 \%(\mathrm{w} / \mathrm{v})$ soluble starch.

\section{SDS PAGE}

A $500-\mu \mathrm{L}$ aliquot of the eluted fraction from Table 2 was concentrated to a volume of $20 \mu \mathrm{L}$ by centrifugal ultrafiltration (Nanosep $10 \mathrm{~K}$ Omega filters, 10,000 Da cut-off; Gelman Laboratory, Ann Arbor, Mich.) and $10 \mu \mathrm{L}$ was added to $10 \mu \mathrm{L}$ of double-strength Laemmli sample buffer [8] and boiled. Samples were subjected to SDS-PAGE (Fig. 5), as described in the Materials and methods. A sample of concentrated supernatant fraction from a culture, the eluted fraction from uncooked corn starch (Table 2), and BioRad Protein Plus molecular weight standards were included in the electrophoresis run. The concentrated supernatant fraction (lane 1) exhibited numerous protein bands, ranging from less than $10 \mathrm{kDa}$ to greater than $150 \mathrm{kDa}$. Starch-binding proteins (lane 2) from the eluted fraction in Table 2 consisted of only two major protein bands, at $105 \mathrm{kDa}$ and $26 \mathrm{kDa}$. These major bands corresponded to minor bands in the crude concentrate in lane 1, consistent with a high level of purification.

\section{Discussion}

This article described the production of extracellular amylase by the psychrotrophic bacterium [11] $A$. psy-

Table 1 Binding to raw starch. An unconcentrated supernatant fraction $(1.0 \mathrm{~mL})$ was treated with a suspension of raw starch granules $(100 \mu \mathrm{L})$ at $0^{\circ} \mathrm{C}$ for $15 \mathrm{~min}$ and then centrifuged at $4^{\circ} \mathrm{C}$ and $15,000 \mathrm{~g}$ for $10 \mathrm{~min}$. The supernatant fraction was collected and assayed using soluble starch as the substrate. Buffer solution $(100 \mu \mathrm{l})$, consisting of $50 \mathrm{mM}$ HEPES, pH 7.0 , and $2 \mathrm{mM} \mathrm{CaCl}_{2}$, was added to the untreated sample. The raw starch suspensions contained $100 \mathrm{mg}$ of raw corn, wheat, or potato starch granules in $50 \mathrm{mM}$ HEPES, $\mathrm{pH} 7.0,2 \mathrm{mM} \mathrm{CaCl}_{2}$

\begin{tabular}{lll}
\hline Treatment & \multicolumn{2}{l}{ Supernatant activity } \\
\cline { 2 - 3 } & Units/mL & Bound (\%) \\
\hline None & 0.071 & 0 \\
Corn starch & 0.041 & 43 \\
Wheat starch & 0.044 & 39 \\
Potato starch & 0.054 & 38 \\
\hline
\end{tabular}


Table 2 Purification of amylase from A. psychrolactophilus. Proteins binding to uncooked corn starch were purified in one step from $1.0 \mathrm{~mL}$ of a concentrated supernatant fraction of a culture. Fractions were assayed using the Sigma infinity amylase reagent

\begin{tabular}{lllllll}
\hline Recovery fraction & $\begin{array}{l}\text { Volume } \\
(\mathrm{mL})\end{array}$ & $\begin{array}{l}\text { Activity } \\
\text { (units/mL) }\end{array}$ & $\begin{array}{l}\text { Protein } \\
(\mu \mathrm{g} / \mathrm{mL})\end{array}$ & $\begin{array}{l}\text { Specific } \\
\text { activity } \\
\text { (units/mg) }\end{array}$ & $\begin{array}{l}\text { Total } \\
\text { activity } \\
\text { (units) }\end{array}$ & Percentage \\
\hline Concentrate & 1.0 & 136 & 609 & 223 & 136 & 100 \\
Flow-through & 1.0 & 88 & 617 & 143 & 88 & 65 \\
$\begin{array}{l}\text { Last washing } \\
\text { Eluted }\end{array}$ & 3.0 & 1 & 0 & - & 3 & 2 \\
\hline
\end{tabular}

chrolactophilus. A. psychrolactophilus apparently produced a single type of extracellular amylase, as evidenced by a single band of amylolytic activity following native PAGE and staining for amylolytic activity. The amylase was probably an $\alpha$-amylase because it was active in the

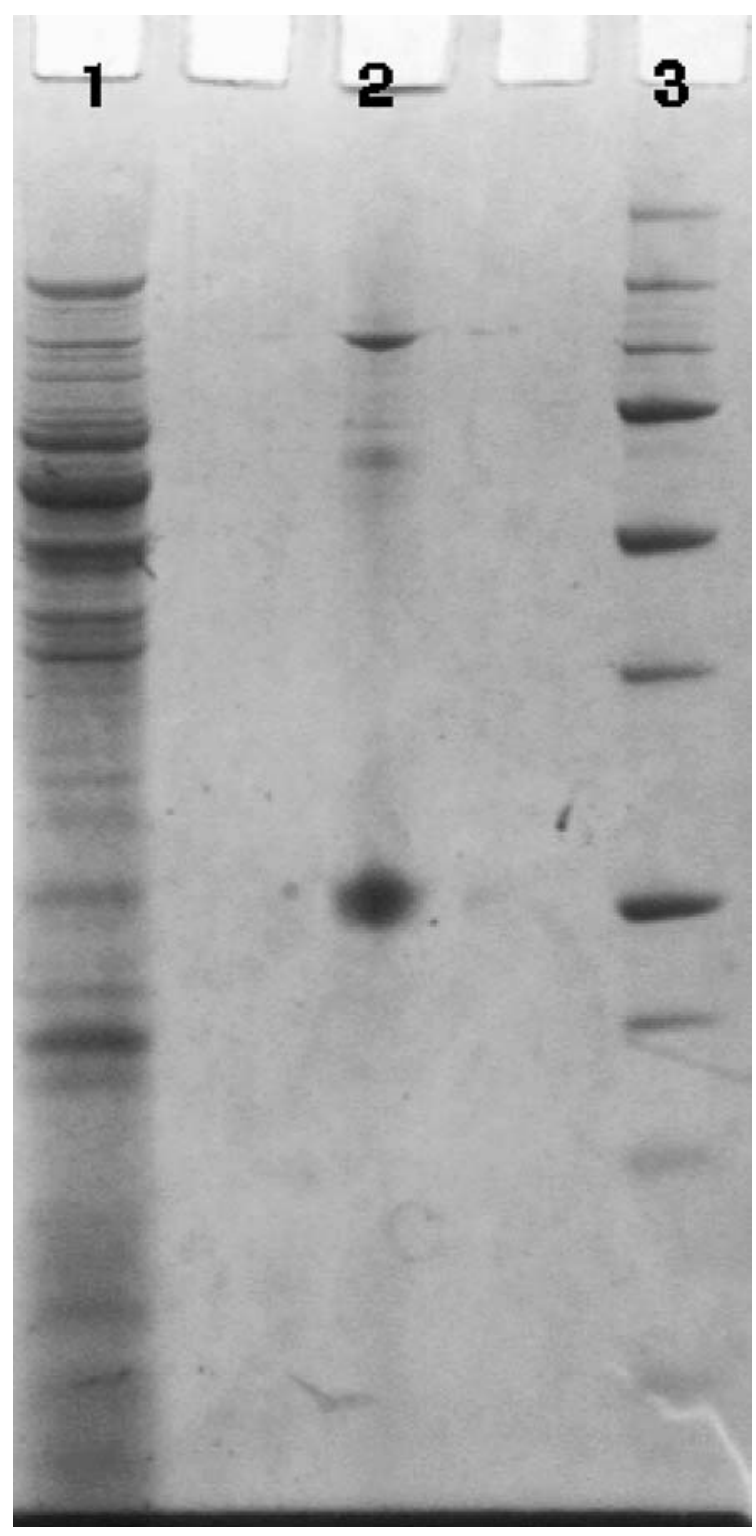

Fig. 5 SDS-PAGE of raw starch-binding proteins. Lane 1 concentrated supernatant fraction from an A. psychrolactophilus culture (6.0 $\mu \mathrm{g}$ of protein), Lane 2 purified amylase preparation $(2.5 \mu \mathrm{g}$ of protein), Lane 3 molecular weight standards (from top, $\times 10^{3} \mathrm{Da}$ : $250,150,100,75,50,37,25,20,15,10$
Phadebas and Sigma assays. The molecular mass of the amylase was estimated using purified preparations, which gave rise to two major raw starch-binding protein bands on SDS gels (105 kDa, $26 \mathrm{kDa})$. It is not possible from the data presented here to know if one or both protein bands possessed amylolytic activity. A size of $26 \mathrm{kDa}$ would make the amylase small compared to most other bacterial amylases, but a size of $105 \mathrm{kDa}$ is well within the range of sizes described for some other bacterial amylases [12]. The 26-kDa starch-binding protein could be a fragment of the $105-\mathrm{kDa}$ protein generated by proteolytic action from proteases, which were known to be present, and it is possible that the $105-\mathrm{kDa}$ protein is a tetramer of the 26-kDa protein. However, we did not observe a possible dimeric form at 52-kDa. Resolution of the issue will need additional research.

Amylase was produced in TSBWD medium with starch, maltose, or no added carbohydrate and reached maximum levels within $96 \mathrm{~h}$ when starch was the growth substrate. Most of the amylase was produced after the end of the period of exponential growth when the growth rate began to slow and when the cultures entered the stationary phase. Amylase was produced even in medium without added carbohydrate, suggesting that starch or maltose were not inducers of amylase production. Protease was produced during the same period that amylase was produced, possibly through induction by a quorum-sensing mechanism. The highest levels of amylase were produced in cultures with starch as the substrate, but growth continued for longer periods. The time of peak amylase concentrations was delayed $24 \mathrm{~h}$ by doubling the starch concentration; and cell densities reached higher levels in medium containing starch than in medium without added carbohydrate. It is therefore not likely that starch or oligosaccharides from starch induced amylase production. The lowest, barely detectable, yields of amylase were produced by cultures growing in glucose medium and we concluded that glucose repressed amylase production in this species.

There is considerable interest in finding amylases that efficiently hydrolyze raw starch at ambient to low temperatures, to reduce costs in producing alcohol and to use in other low-temperature applications [15]. Psychrophilic amylases from psychrotrophic bacteria have been described which have temperature optima in the range $25-30^{\circ} \mathrm{C}$ [3-5]. These enzymes are reported to have much greater catalytic efficiency at temperatures of $0-20^{\circ} \mathrm{C}$ and poorer thermal stability than do mesophilic amylases with temperature optima of $50-70^{\circ} \mathrm{C}$ [4]. They would probably be better suited than most mesophilic 
amylases for applications requiring temperatures below $30^{\circ} \mathrm{C}$, but their poor thermal stability would limit their utility within the ambient temperature range. There is much interest in the structures of the amylases in order to understand the relationship between protein structure and thermal stability; and it is thought that high activity at low temperatures is correlated with greater flexiblity of psychrophilic amylase chains compared to mesophilic amylase chains. The activity of these psychrophilic amylases on raw starch has not been reported.

The amylase from the psychrotrophic bacterium A. psychrolactophilus appeared to be a mesophilic amylase because it had a temperature maximum on soluble starch between $40^{\circ} \mathrm{C}$ and $50^{\circ} \mathrm{C}$ and might not be as well suited to applications below $30^{\circ} \mathrm{C}$ as psychrophilic amylases. The amylase is of interest to us however because it binds to uncooked starch granules, a feature strongly correlated with the hydrolysis of raw starch [7], and it has a temperature optimum near the low end of the mesophilic range of amylases. These properties make the amylase best suited for applications at ambient to slightly above ambient temperatures, where some industrial fermentations occur.

\section{References}

1. Barnes WA, Blakeney A (1974) Determination of cereal alpha amylase using a commercially available dye-labelled substrate. Die Starke 26:193-197

2. Bradford M (1976) A rapid and sensitive method for the quantitation of microgram quantities of protein utilizing the principle of protein-dye binding. Anal Biochem 72:248-254

3. Chessa J, Feller G, Gerday C (1999) Purification and characterization of the heat-labile $\alpha$-amylase secreted by the psychrophilic bacterium TAC 240B. Can J Microbiol 45:452-457
4. Feller G, Narinx E, Arpigny J, Zekhnini Z, Swings J, Gerday C (1994) Temperature dependence of growth, enzyme secretion and activity of psychrophilic antarctic bacteria. Appl Microbiol Biotechnol 41:477-479

5. Feller G, Payan F, Theys F, Quian M, Haser R, Gerday C (1994) Stability and structural analysis of $\alpha$-amylase from the antarctic psychrophile Alteromonas haloplanctis A23. Eur J Biochem 222:441-447

6. Girard C, Michaud D (2002) Direct monitoring of extracellular protease activities in microbial cultures. Anal Biochem 308:388-391

7. Hamilton L, Kelley C, Fogarty W (1998) Raw starch degradation by the non-raw starch-absorbing bacterial alpha amylase of Bacillus sp. IMD 434. Carbohydr Res 314:251-257

8. Laemmli U (1970) Cleavage of structural proteins during the assembly of the head of bacteriophage T4. Nature 227:680-685

9. Loveland J, Gutsall K, Kasmir J, Prema P, Brenchley J (1994) Characterization of psychrotrophic microorganisms producing $\beta$-galactosidase activities. Appl Environ Microbiol 60:12-18

10. Loveland-Curtze J, Sheridan P, Gutshell K, Brenchley J (1999) Biochemical and phylogenetic analyses of psychrophilic isolates belonging to the Arthrobacter subgroup and description of Arthrobacter psychrolactophilus, sp. nov. Arch Microbiol 171:355-363

11. Morita R (1975) Psychrophilic bacteria. Bacteriol Rev 39:144167

12. Pandey A, Nigam P, Soccol C, Soccol V, Singh D, Mohan R (2000) Advances in microbial amylases. Biotechnol Appl Biochem 31:135-152

13. Sarath G, de la Motte R, Wagner F (1989) Protease assay methods. In: Beynon RJ, Bond JS (eds) Proteolytic enzymes a practical approach. IRL, Oxford, p 28

14. Sumner J, Howell S (1935) A method for the determination of saccharase activity. J Biol Chem 108:51-54

15. Textor S, Hill A, MacDonald D, St. Denis E (1998) Cold enzyme hydrolysis of wheat starch granules. Can J Chem Eng 76:87-93

16. Trimbur D, Gutshall K, Prema P, Brenchley J (1994) Characterization of a psychrotrophic Arthrobacter gene and its coldactive $\beta$-galactosidase. Appl Environ Microbiol 60:4544-4552 